\title{
Antioxidative Amino Acids in Early Enteral Versus Parenteral Nutrition Following Major Rectal Surgery
}

Citation for published version (APA):

Smeets, B. J., Heesakkers, F. F., Huijbregts, C. P., Luyer, M. D., Bakker, J. A., Roos, A. N., Rutten, H. J., Bouvy, N. D., \& Boelens, P. G. (2020). Antioxidative Amino Acids in Early Enteral Versus Parenteral Nutrition Following Major Rectal Surgery. Critical Care Medicine, 48(10), E990-E991.

https://doi.org/10.1097/CCM.0000000000004516

Document status and date:

Published: 01/10/2020

DOI:

10.1097/CCM.0000000000004516

Document Version:

Publisher's PDF, also known as Version of record

Document license:

Taverne

Please check the document version of this publication:

- A submitted manuscript is the version of the article upon submission and before peer-review. There can be important differences between the submitted version and the official published version of record.

People interested in the research are advised to contact the author for the final version of the publication, or visit the DOI to the publisher's website.

- The final author version and the galley proof are versions of the publication after peer review.

- The final published version features the final layout of the paper including the volume, issue and page numbers.

Link to publication

\footnotetext{
General rights rights.

- You may freely distribute the URL identifying the publication in the public portal. please follow below link for the End User Agreement:

www.umlib.nl/taverne-license

Take down policy

If you believe that this document breaches copyright please contact us at:

repository@maastrichtuniversity.nl

providing details and we will investigate your claim.
}

Copyright and moral rights for the publications made accessible in the public portal are retained by the authors and/or other copyright owners and it is a condition of accessing publications that users recognise and abide by the legal requirements associated with these

- Users may download and print one copy of any publication from the public portal for the purpose of private study or research.

- You may not further distribute the material or use it for any profit-making activity or commercial gain

If the publication is distributed under the terms of Article $25 \mathrm{fa}$ of the Dutch Copyright Act, indicated by the "Taverne" license above, 
the treatment-dose heparin for primary prevention, $60 \%$ of the experts responded considered multimodal thromboprophylaxis to include mechanical methods. As a result, the dose should be determined based on the risk-benefit balance. Several clinical trials comparing different doses of heparins are planned or initiated (https://clinicaltrials.gov/ ct $2 /$ results? cond $=$ COVID-19\&term $=$ low-molecular-weight heparin $\&$ cntry $=\&$ state $=\& \operatorname{cit} y=\&$ dist $=$ ). Until we achieve definitive results, we agree with the many societies that state that the standard prophylaxis dose should be used. In addition to ISTH, World Health Organization, National Institute of Health, all recommend standard prophylactic dose heparin. Recently, Klok et al (6) reported the crude cumulative frequency of the thrombosis was $57 \%$ (95\% CI, 47-67\%), even though the patients received pharmacological thromboprophylaxis. Although it is understandable to think that a higher dose of anticoagulation is necessary, the use of higher doses of anticoagulation does not appear to decrease allcause mortality (hazard ratio, $0.79,95 \% \mathrm{CI}, 0.35-1.8$ ).

Dr. Connors' institution received funding from CSL Behring, and she received funding from Abbott, Portola, Takeda, and Bristol-Myers Squibb. The remaining authors have disclosed that they do not have any potential conflicts of interest.

Toshiaki Iba, MD, Department of Emergency and Disaster Medicine, Juntendo University Graduate School of Medicine, Tokyo, Japan; Jerrold H. Levy, MD, Department of Anesthesiology, Critical Care, and Surgery, Duke University School of Medicine, Durham, NC; Marcel Levi, MD, Department of Medicine and Cardiometabolic ProgrammeNIHR UCLH/UCL BRC, University College London Hospitals NHS Foundation Trust, London, United Kingdom; Jean Marie Connors, MD, Hematology Division Brigham and Women's Hospital, Harvard Medical School, Boston, MA; Jecko Thachil, MD, Department of Haematology, Manchester Royal Infirmary, Manchester, United Kingdom

\section{REFERENCES}

1. Piagnerelli M, Cauchie P, Wautrecht J-C: Optimizing the Risk-Benefit Balance of Thromboprophylaxis in Critically III Patients With Coronavirus Disease 2019. Crit Care Med 2020; 48:e988-e989

2. Iba T, Levy JH, Levi M, et al: Coagulopathy of coronavirus disease 2019. Crit Care Med 2020; 48:1358-1364

3. Thachil J, Tang N, Gando S, et al: ISTH interim guidance on recognition and management of coagulopathy in COVID-19. J Thromb Haemost 2020; 18:1023-1026

4. Bikdeli B, Madhavan MV, Jimenez D, et al; Global COVID-19 Thrombosis Collaborative Group, Endorsed by the ISTH, NATF, ESVM, and the IUA, Supported by the ESC Working Group on Pulmonary Circulation and Right Ventricular Function: COVID-19 and thrombotic or thromboembolic disease: Implications for prevention, antithrombotic therapy, and follow-up: JACC state-of-the-art review. $J$ Am Coll Cardiol 2020; 75:2950-2973

5. Spyropoulos AC, Levy JH, Ageno W, et al: Clinical guidance on the diagnosis, prevention and treatment of venous thromboembolism in hospitalized patients with COVID-19. J Thromb Haemost 2020 May 27. [online ahead of print]

6. Klok FA, Kruip MJHA, van der Meer NJM, et al: Confirmation of the high cumulative incidence of thrombotic complications in critically ill ICU patients with COVID-19: An updated analysis. Thromb Res 2020; $191: 148-150$

DOI: $10.1097 / C C M .0000000000004530$

\section{Antioxidative Amino Acids in Early Enteral Versus Parenteral Nutrition Following Major Rectal Surgery}

\section{To the Editor:}

$\mathrm{F}$ ollowing major rectal surgery, postoperative ileus is common and few patients reach nutritional goals in the first days after surgery. A previous trial randomized patients to receive supplementary early enteral versus parenteral nutrition after major rectal surgery. Enteral nutrition was superior, as patients experienced less postoperative ileus and anastomotic leakage when compared with patients receiving parenteral nutrition (1).

To study the underlying mechanisms, we previously published a substudy in Critical Care Medicine on plasma concentrations of conditionally essential amino acids in patients randomized to early enteral versus parenteral nutrition (2). Postoperative plasma concentrations of glutamine and arginine were lower in patients receiving enteral nutrition, while better clinical outcomes were observed when compared with patients receiving parenteral nutrition (2). Consequently, other mechanisms were postulated to have played a role in the beneficial effects of enteral nutrition. Here, we present additional analyses of plasma concentrations of antioxidative amino acids that were previously unavailable.

This was a substudy of a prospective, single-center, randomized controlled trial including 123 patients undergoing surgical resection of primary locally advanced or recurrent rectal carcinoma. The aim was to investigate whether the route of supplementary nutrition early after major rectal surgery affected postoperative plasma concentrations of antioxidative amino acids (taurine, hydroxyproline, glutamic acid, glycine, and $\mathrm{N}$-acetylcysteine). Furthermore, amino acid concentrations were studied in relation to clinical outcomes. For additional information on methodology, see the Methods section in our previous publication (2).

Baseline characteristics were similar between groups (2). No differences were seen between groups in rate of advancement in oral diet. Since exact nutritional value of oral intake could not be registered, cumulative intake of amino acids via artificial route was calculated over the first 5 postoperative days (PODs).

Cumulative intake of total amino acids $(p=0.037)$, glycine $(p<0.001)$, and glutamine $(p<0.001)$ was higher in the parenteral group, while cumulative intake of cysteine was higher in the enteral group $(p<0.001)$. Cumulative intake of proline was similar between groups $(p=0.278)$.

$\mathrm{N}$-acetylcysteine was not detectable in any blood sample. At baseline, plasma concentrations of all amino acids were comparable between groups (Table 1). Glycine concentrations were lower in the enteral group on POD $1(p=0.003)$ and POD 5 ( $p=0.005)$ when compared with the parenteral group. No other differences between groups were observed. Taurine concentrations on POD 1 correlated with occurrence of anastomotic leakage $(r=0.211 ; p=0.024)$. Proline concentrations on POD 1 
TABLE 1. Plasma Amino Acid Concentrations ( $\mu \mathrm{mol} / \mathrm{L}$ ) After Major Rectal Surgery

\begin{tabular}{lccccc} 
Amino Acid & Day & $\begin{array}{c}\text { Early Enteral } \\
\text { Nutrition }(\boldsymbol{n}=\mathbf{5 6})\end{array}$ & $\begin{array}{c}\text { Early Parenteral } \\
\text { Nutrition }(\boldsymbol{n}=\mathbf{6 1})\end{array}$ & $\boldsymbol{p}$ & $\begin{array}{c}\text { Effect Size } \\
(\mathbf{9 5} \% \mathbf{C l})\end{array}$ \\
\hline Taurine & 0 & $44.50(33.00-56.00)$ & $48.00(35.00-60.50)$ & 0.555 & $-0.09(-0.46$ to 0.27$)$ \\
& 1 & $33.00(21.50-40.75)$ & $35.00(28.50-44.00)$ & 0.138 & $-0.34(-0.70$ to 0.03$)$ \\
Glutamic acid & 5 & $29.00(19.75-38.00)$ & $32.50(23.00-45.75)$ & 0.108 & $-0.35(-0.72$ to 0.02$)$ \\
& 0 & $35.50(27.25-42.75)$ & $33.00(26.00-45.00)$ & 0.950 & $-0.08(-0.45$ to 0.28$)$ \\
& 1 & $30.50(21.75-35.00)$ & $30.00(22.00-39.00)$ & 0.913 & $0.05(-0.32$ to 0.42$)$ \\
Glycine & 5 & $32.50(25.00-43.25)$ & $37.50(28.50-51.75)$ & 0.062 & $-0.34(-0.70$ to 0.04$)$ \\
& 0 & $172.00(143.50-221.25)$ & $172.00(144.00-202.00)$ & 0.787 & $-0.10(-0.46$ to 0.26$)$ \\
& 1 & $142.50(117.00-176.25)$ & $170.00(140.50-197.50)$ & $\mathbf{0 . 0 0 3}$ & $-0.55(-0.91$ to -0.17$)$ \\
Hydroxyproline & 5 & $133.50(113.25-182.50)$ & $170.00(142.00-209.75)$ & $\mathbf{0 . 0 0 5}$ & $-0.58(-0.95$ to -0.20$)$ \\
& 0 & $5.00(4.00-8.00)$ & $5.00(3.00-7.00)$ & 0.115 & $0.37(0.00-0.73)$ \\
& 1 & $2.00(1.00-3.25)$ & $2.00(0.00-3.00)$ & 0.268 & $0.20(-0.17$ to 0.57$)$ \\
& 5 & $2.00(1.00-4.00)$ & $2.50(1.00-4.00)$ & 0.860 & $0.08(-0.28$ to 0.45$)$ \\
\hline
\end{tabular}

Values are presented as median (interquartile range). Boldface entries are statistically significant values.

$(r=-0.246 ; p=0.008)$ correlated with occurrence of early ileus. No other significant correlations were found. Multivariable regression analysis revealed no significant correlations between any plasma amino acid concentration and clinical outcomes.

In conclusion, postoperative amino acid plasma concentrations were lower or similar in the enteral group, while a better clinical outcome was observed when compared with the parenteral group. However, plasma concentrations were not directly associated with clinical outcomes. As such, we postulate that changes in amino acid concentrations may be considered as an epiphenomenon to a diseased state, rather than a valid contributor to impaired surgical convalescence (3). Other studies are needed to explain the beneficial effect of enteral nutrition following major rectal surgery.

This preplanned substudy was funded by Maastricht University Medical Center, Department of General Surgery. The original study was supported by an unconditional, nonrestrictive research grant by Nutricia Netherlands BV, Zoetermeer, The Netherlands.

Dr. Smeets's institution received funding from Maastricht University Medical Center, Department of General Surgery, and from Nutricia Netherlands BV, Zoetermeer, The Netherlands. Dr. Luyer's institution received funding from Nutricia, ZonMw, Fondsnutsohra, Medtronic, Dutch Cancer Foundation, and Galvani. The remaining authors have disclosed that they do not have any potential conflicts of interest.

Boudewijn J. Smeets, PhD, Department of Surgery, Catharina Hospital Eindhoven, Eindhoven, The Netherlands, and GROW School of Oncology and Developmental Biology, Maastricht University, Maastricht, The Netherlands; Fanny F.

Heesakkers, MANP, Claudia P. Huijbregts, MD, Misha D. Luyer, PhD, Department of Surgery, Catharina Hospital Eindhoven, Eindhoven, The Netherlands; Jaap A. Bakker, PhD, Department of Clinical Chemistry, Leiden University Medical Center, Leiden, The Netherlands, and Department of Clinical Genetics, Maastricht University Medical Center, Maastricht, The Netherlands; Arnout N. Roos, PhD, Department of Intensive Care Medicine, Catharina Hospital Eindhoven, Eindhoven, The Netherlands; Harm J. Rutten, PhD, Department of Surgery, Catharina Hospital Eindhoven, Eindhoven, The Netherlands, and GROW School of Oncology and Developmental Biology, Maastricht University, Maastricht, The Netherlands; Nicole D. Bouvy, PhD, Department of Surgery, Maastricht University Medical Center, Maastricht, The Netherlands; Petra G. Boelens, PhD, Department of Rehabilitation Medicine, Rijndam Rehabilitation, Erasmus MC University Medical Center, Rotterdam, The Netherlands

\section{REFERENCES}

1. Boelens PG, Heesakkers FF, Luyer MD, et al: Reduction of postoperative ileus by early enteral nutrition in patients undergoing major rectal surgery: Prospective, randomized, controlled trial. Ann Surg 2014; 259:649-655

2. van Barneveld KWY, Smeets BJJ, Heesakkers FFBM, et al: Beneficial Effects of Early Enteral Nutrition After Major Rectal Surgery: A Possible Role for Conditionally Essential Amino Acids? Results of a Randomized Clinical Trial. Crit Care Med 2016; 44:e353-e361

3. Gunst J, Vanhorebeek I, Thiessen SE, et al: Amino acid supplements in critically ill patients. Pharmacol Res 2018; 130:127-131

DOI: $10.1097 / \mathrm{CCM} .0000000000004516$

\section{A Centrally Acting Antihypertensive, Clonidine, Sedates Patients Presenting With Acute Respiratory Distress Syndrome Evoked by Severe Acute Respiratory Syndrome-Coronavirus 2}

\section{To the Editor:}

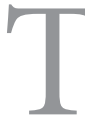

he severe acute respiratory syndrome-coronarovirus 2 pandemics overwhelmed the critical care units (CCUs) in Alsace, France. The disease evokes acute respiratory 